\title{
Using Pollution Load Index (PLI) and Geoaccumulation Index (I-Geo) for the Assessment of Heavy Metals Pollution in Tigris River Sediment in Baghdad Region
}

\author{
Adel Mashaan Rabee*, Yaaroub Faleh Al-Fatlawy*, Abd-Al-Husain Najim Abd own** and \\ Mustafa Nameer* \\ *Department of Biology, College of Science, University of Baghdad. \\ **Ministry of Science and Technology.
}

\begin{abstract}
Six stations along Tigris river in Baghdad region were chosen to collect and assess the $\mathrm{Mn}, \mathrm{Ni}$, $\mathrm{Pb}, \mathrm{Cu}$ and $\mathrm{Cd}$ contamination in sediments by using pollution load index (PLI) and geo-accumulation index (I-geo). Cd was found at the lowest concentration ranged between 0.3$1.3 \mu \mathrm{g} / \mathrm{g}$ dry weight. Whereas, Mn was the highest ranging between $166-426 \mu \mathrm{g} / \mathrm{g}$ dry weight. Geo-accumulation index indicates that the sediment in the most of studied stations were slightly polluted (grade 1) with respect to $\mathrm{Pb}$ and $\mathrm{Cd}$, while the sediments in all studied stations were unpolluted (grade 0) with respect to $\mathrm{Mn}, \mathrm{Cu}$ and $\mathrm{Ni}$. The values of Pollution Load Index (PLI) were found to be very low, and varied between 0.301-0.970, indicating that the studied stations in Tigris river were unpolluted by total of studied heavy metals.
\end{abstract}

\section{Introduction}

In the recent past, there have been increasing interests regarding heavy metal contaminations in the environments, apparently due to their toxicity and perceived persistency within the aquatic systems (1). There are basically three reservoirs of metals in the aquatic environment: water, sediment and biota (2). The analysis of river sediment is a useful method of studying environmental pollution with heavy metals $(3,4)$. Heavy metals accumulate in the sediments through complex physical and chemical adsorption mechanisms depending on the nature of the sediment matrix and the properties of the adsorbed compounds (5).

The occurrence of elevated concentrations of trace metals in sediments found at the bottom of the water column can be a good indicator of man induced pollution rather than natural enrichment of the sediment by geological weathering (6). The assessment of sediment enrichment with elements can be carried out in many ways. The most common ones are the index of geo-accumulation (I-geo) and pollution load index (PLI). The I-geo has been widely utilized as a measure of pollution in freshwater sediment (7), while the pollution load index (PLI) represents the number of times by which the heavy metal concentrations in the sediment exceeds the background concentration, and gives a summative indication of the overall level of heavy metal toxicity in a particular sample (8). Concentrations of metals in sediment of the Iraqi waters have been documented by $(9,10$, 11, 12 and 13). This study can be considered the first attempt to evaluate the heavy metals pollution in sediments of Tigris River sediment by using pollution load index and geoaccumulation index.

\section{Description of study area}

Tigris river is one of the most important twin rivers in Iraq, sharing with Euphrates river as the main sources for man use, especially for drinking water since they cross the major cities in the country. Tigris is nearly $2000 \mathrm{~km} \mathrm{long}$, of which $1360 \mathrm{~km}$ runs through Iraq, rising in the Taurus mountains of eastern Turkey and flowing in a generally southeasterly direction until it joins the Euphrates near in southern Iraq. From north to south, five tributaries drain into the river: the Khabour, Greater and Lesser Zap, Adheym and the Diyala. All these tributaries, with the initial force provided by steep slopes, carry their erosion products into the plain, where they join the Euphrates (14). The Tigris river is heavily dammed in Iraq and Turkey, to provide water for irrigating the arid and semi-desert regions bordering the river valley. Damming has also been important for averting floods in Iraq. Recent Turkish damming of the river has been 
the subject of some controversy, both for its environmental effects within Turkey and its potential to reduce the flow of water downstream. In the present study six stations were chosen from Tigris river in Baghdad (Fig.(1)), these were, station 1 (Al-Tarmiyah), station 2 (Al-Adamiah city), station 3 (Al-Utafiah), station 4(Al-Jadiriah), station 5 (Al-Rasheed) and station 6 (Al-Zafaraniah).

\section{Materials and Methods}

\section{v Sampling}

Samples of sediments were taken from six stations (covering the Tigris river in Baghdad region) during May and September 2008 which corresponds to low and high level of water discharge seasons. The River sediment samples were collected by using clean plastic scoop and stored in polyethylene bags. The concentrations of $\mathrm{Mn}, \mathrm{Ni}, \mathrm{Pb}, \mathrm{Cu}$ and $\mathrm{Cd}$ were determined in all samples using Atomic absorption Spectrophotometer (Perkin-Elemer model 5000) with standard solutions in a similar manner to that described by Smith et al. (15) and Abaychi \& Douabul (16).

\section{$\checkmark$ Sediment pollution indices}

The geo-accumulation index (I-geo) and pollution load index (PLI) were employed to assess the pollution of metals in the sediment of Tigris river.

\section{Geo-accumulation index (I-geo)}

Geo-accumulation index was determined by the following equation according to Müller (17) which was described by Boszke et al (18).

$\mathrm{I}$-geo $=\log 2(\mathrm{Cn} / 1.5 \mathrm{Bn})$

where,

$\mathrm{Cn}=$ Measured concentration of heavy metal in the Tigris sediment.

$\mathrm{Bn}=$ Geochemical background value in average shale (19) of element $\mathrm{n}$. The factor 1.5 is used for the possible variations of the background data due to lithological variations.

I-geo was classified into seven grades: I-geo $\leq 0$ (grade 0$)$, unpolluted; $0<$ I-geo $\leq 1$ (grade 1), slightly polluted; $1<$ I-geo $\leq 2$ (grade 2), moderately polluted; $2<$ I-geo $\leq 3$ (grade 3), moderately severely polluted; $3<$ I-geo $\leq 4$ (grade 4), severely polluted; $4<$ I-geo $\leq 5$ (grade 5), severely extremely polluted; I-geo $>5$ (grade 6), extremely polluted (17).
2. The Pollution Load Index (PLI)

The Pollution Load Index (PLI) is obtained as concentration Factors (CF). This $\mathrm{CF}$ is the quotient obtained by dividing the concentration of each metals. The PLI of the place are calculated by obtaining the n-root from the nCFs that were obtained for all the metals. With the PLI obtained from each place (20). Generally pollution load index (PLI) as developed by Tomlinson et al (21), which is as follows:

$$
\begin{aligned}
& \mathrm{CF}=\mathrm{C} \text { metal } / \mathrm{C} \text { background value } \\
& \mathrm{PLI}=\sqrt[\mathrm{n}]{(\mathrm{CF} 1 \mathrm{xCF} 2 \mathrm{xCF} 3 \mathrm{x} . . \mathrm{xCFn})}
\end{aligned}
$$

Where,

$\mathrm{CF}=$ contamination factor, $\mathrm{n}=$ number of metals

$\mathrm{C}$ metal $=$ metal concentration in polluted sediments

$\mathrm{C}$ Background value $=$ background value of that metal.

The PLI value of $>1$ is polluted, whereas $<1$ indicates no pollution (22).

The world average concentration of $\mathrm{Cu}$ (45 $\mu \mathrm{g} / \mathrm{g})$, Ni $(68 \mu \mathrm{g} / \mathrm{g}), \mathrm{Mn}(900 \mu \mathrm{g} / \mathrm{g}), \mathrm{Pb}$ $(20 \mu \mathrm{g} / \mathrm{g})$, and $\mathrm{Cd}(0.3 \mu \mathrm{g} / \mathrm{g})$ reported for shale (19) were considered as the background value.

\section{Results and Discussion The metals concentration}

The concentrations of heavy metals in sediments are varied according to the rate of particle sedimentation, the rate of heavy metals deposition, the particle size and the presence or absence of organic matter in the sediments (23).

The concentration of $\mathrm{Mn}, \mathrm{Ni}, \mathrm{Pd}, \mathrm{Cu}$ and $\mathrm{Cd}$ in Tigris sediments observed in this study ranging between 166 - 426, 6 - 30, 7 - 90, 5-55 and $0.3-1.3 \mu \mathrm{g} / \mathrm{g}$ dry weight sediment respectively. These values were similar to that reported in Tigris river except $\mathrm{Cd}$ which was higher in the present study $(9,11)$. Mn recorded high concentrations when compared with other studied metals (Table (1)).This may be due to the high concentration of this metals in suspended solids. Gessey et al (24) stated that heavy metals react readily with suspended particulate matters and through sedimentation processes, accumulate in bottom deposits. 


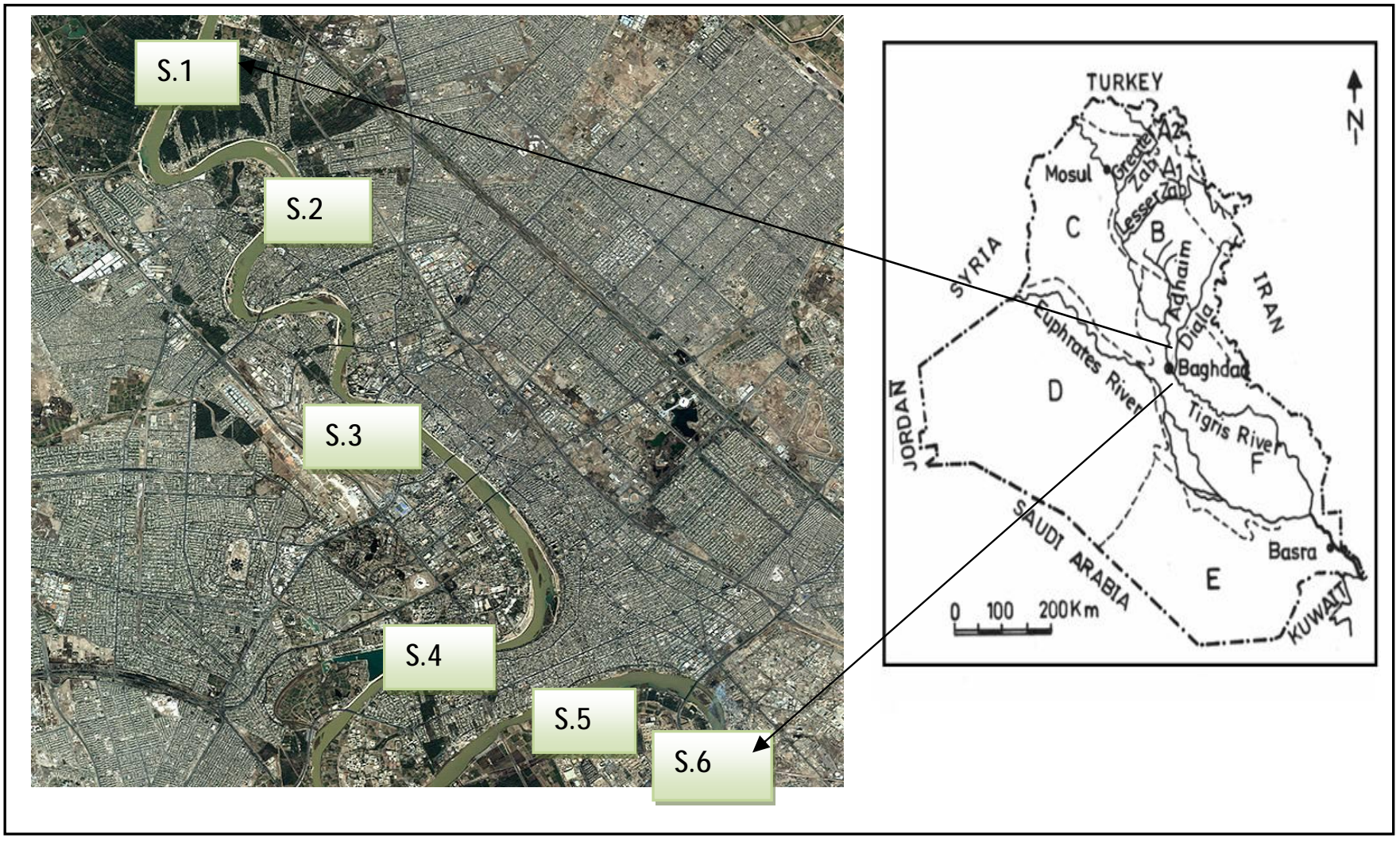

Fig.(1) Map of Iraq showing the sample locations on Tigris river in Baghdad region.

Table (1)

Mean and standard deviation for the studied metals in sediment of Tigris River.

\begin{tabular}{|c|c|c|c|c|c|}
\hline Stations & $\begin{array}{c}M n \\
\mu g g-1\end{array}$ & $\begin{array}{c}N i \\
\mu g g-1\end{array}$ & $\begin{array}{c}P b \\
\mu g g-1\end{array}$ & $\begin{array}{c}C u \\
\mu g g-1 \\
\end{array}$ & $\begin{array}{c}C d \\
\mu g g-1\end{array}$ \\
\hline Station 1 & $\begin{array}{c}160 \pm 11.3 \\
\text { a }\end{array}$ & $\begin{array}{c}12 \pm 8 \\
\mathbf{a}\end{array}$ & $\begin{array}{c}8 \pm 2.1 \\
\text { a }\end{array}$ & $\begin{array}{c}7 \pm 3.3 \\
\mathbf{a}\end{array}$ & $\begin{array}{c}0.4 \pm 0.07 \\
a\end{array}$ \\
\hline Station 2 & $\begin{array}{c}207 \pm 10.6 \\
\text { a }\end{array}$ & $\begin{array}{c}11 \pm 2.8 \\
\mathrm{a}\end{array}$ & $\begin{array}{c}13 \pm 3.5 \\
\mathbf{a}\end{array}$ & $\begin{array}{c}14 \pm 2.1 \\
\text { b }\end{array}$ & $\begin{array}{c}0.42 \pm 0.03 \\
\mathrm{a}\end{array}$ \\
\hline Station 3 & $\begin{array}{c}292 \pm 127 \\
\text { b }\end{array}$ & $\begin{array}{c}25 \pm 6.3 \\
\quad b\end{array}$ & $\begin{array}{c}42 \pm 17.6 \\
b\end{array}$ & $\begin{array}{c}40 \pm 11.3 \\
\text { c }\end{array}$ & $\begin{array}{c}0.9 \pm 0.28 \\
b\end{array}$ \\
\hline Station 4 & $\begin{array}{c}328 \pm 138 \\
b\end{array}$ & $\begin{array}{c}25 \pm 0.7 \\
\quad b\end{array}$ & $\begin{array}{c}39 \pm 14.8 \\
b\end{array}$ & $\begin{array}{c}35 \pm 6.3 \\
c\end{array}$ & $\begin{array}{c}0.95 \pm 0.49 \\
\text { b }\end{array}$ \\
\hline Station 5 & $\begin{array}{c}279 \pm 92 \\
\text { c }\end{array}$ & $\begin{array}{c}22 \pm 9.1 \\
\quad b\end{array}$ & $\begin{array}{c}59 \pm 43.8 \\
b\end{array}$ & $\begin{array}{c}43 \pm 16.9 \\
c\end{array}$ & $\begin{array}{c}0.9 \pm 0.42 \\
b\end{array}$ \\
\hline Station 6 & $\begin{array}{c}325 \pm 78 \\
\text { c }\end{array}$ & $\begin{array}{c}19 \pm 0.3 \\
\quad b\end{array}$ & $\begin{array}{c}45 \pm 31.8 \\
b\end{array}$ & $\begin{array}{c}37 \pm 9.1 \\
\text { c }\end{array}$ & $\begin{array}{c}0.85 \pm 0.48 \\
b\end{array}$ \\
\hline
\end{tabular}

Letters differed in vertical rows refer to significant differences. 
Results of statistical analysis showed that concentrations of metals in sediment increased in southern stations inside Baghdad area (Table (1)), this may be attributed to the increase of industrial activities in this region. The major source for the metal contamination in rivers is the industrial effluents near this rivers, as well as the transport of small fraction of sediment downstream due to the river velocity contributes to the accumulation of heavy metals in lower parts (6).

Comparing the concentration of metals in sediment between high and low discharges period, it seemed that the concentration is more in low discharge (except $\mathrm{Mn}$ ) than high discharge period, and this may be due to the dilution factor related to the high discharge in May (12).

According to the correlation coefficient results a very high positive correlation with a very significant probability $(\mathrm{P} \leq 0.01)$ was observed between $\mathrm{Cu} / \mathrm{Cd}, \mathrm{Pb} / \mathrm{Cu}, \mathrm{Cd} / \mathrm{Pb}$ and $\mathrm{Cu} / \mathrm{Ni}$. A high correlation $(\mathrm{P} \leq 0.01)$ was also noticed between $\mathrm{Cd} / \mathrm{Ni}$ and $\mathrm{Pb} / \mathrm{Ni}$.

\section{geo-accumulation index}

The geo-accumulation index is a quantitative measure of the degree of pollution in aquatic sediments (25). It consists of seven grades ranging from unpolluted to very extremely polluted.

Table (2) presents the geo-accumulation index for the quantification of heavy metal accumulation in the study area. The I-geo grades for the study area sediments varies from metal to metal and site to site (across metals and sites). Manganese, Nickle and Cooper remain in grade 0 (unpolluted) in all stations suggesting that the study area sediments are in background value with respect to this metal. The I-geo for $\mathrm{Pb}$ and $\mathrm{Cd}$ attain grade 0 in station 1 and station 2 (unpolluted), while, attain in grade 1 in other stations which indicates that sediments of these stations were slightly polluted by $\mathrm{Pb}$ and $\mathrm{Cd}$.

The I-geo showed that all heavy metals are in grade 0 and grade 1 (Table (2)). This suggests that the sediments of Tigris river are having background concentrations for $\mathrm{Mn}, \mathrm{Cu}$, and $\mathrm{Ni}$, and these elements are practically unchanged by anthropogenic influences, while the concentration of $\mathrm{Pb}$ and $\mathrm{Cd}$ exceeded the average shale value. These dangerous metals may be derived from industrial waste and gasoline additives used, in the factories and cars (26). These elements may also be derived through corrosion of the numerous abandoned launches along the river and agricultural activities.

\section{Pollution load index}

Pollution severity and its variation along the sites was determined with the use of pollution load index. This index is a quick tool in order to compare the pollution status of different places (27).

Results of the present study show that the $\mathrm{CF}$ values of most of the metals such as $\mathrm{Mn}$, $\mathrm{Cu}$, and $\mathrm{Ni}$ in the study area are low $(<1)$ (Table (3)). But, CF values for metals like $\mathrm{Pb}$. and $\mathrm{Cd}$ shows higher $(>1)$ values due to the influence of external discrete sources like industrial activities, agricultural runoff and other anthropogenic inputs. The values of Pollution Load Index (Table (3)) were found to be generally low $(<1)$ in all the studied stations. The difference in indices results due to the difference in sensitivity of these indices towards the sediment pollutants (28). These confirmed that Tigris river is facing probable environmental pollution especially with dangerous heavy metals $(\mathrm{Pb}$ and $\mathrm{Cd}$ ) which result from increased rate of non-treatment industrial waste which are discharged to Tigris river. 
Table (2)

Geo-accumulation index for studied heavy metals in sediment of Tigris River.

\begin{tabular}{||c||c||c||c|c|c|}
\hline stations & I-geo $\mathbf{M n}$ & I-geo $\mathbf{N i}$ & I-geo Pb & I-geo $\mathbf{C u}$ & I-geo $C d$ \\
\hline \hline Station 1 & -2.0 & -2.14 & -1.20 & -2.12 & -0.11 \\
Station 2 & -1.75 & -2.22 & -0.76 & -1.49 & -0.35 \\
Station 3 & -1.41 & -1.36 & 0.36 & -0.51 & 0.69 \\
Station 4 & -1.29 & -1.36 & 0.28 & -0.64 & 0.74 \\
Station 5 & -1.45 & -1.51 & 0.67 & -0.44 & 0.69 \\
Station 6 & -1.30 & -1.68 & 0.42 & -0.56 & 0.63 \\
\hline
\end{tabular}

Table (3)

Contamination factor and pollution load index for metals in sediments of Tigris River.

\begin{tabular}{|c||c||c||c||c||c||c|}
\hline Stations & $C F$ Mn & $C F ~ N i$ & $C F ~ P b$ & $C F C u$ & $C F C d$ & $P L I$ index \\
\hline \hline Station 1 & 0.17 & 0.17 & 0.42 & 0.16 & 1.30 & 0.30 \\
Station 2 & 0.23 & 0.16 & 0.67 & 0.32 & 1.40 & 0.40 \\
Station 3 & 0.32 & 0.38 & 2.12 & 0.88 & 3.00 & 0.92 \\
Station 4 & 0.36 & 0.38 & 1.90 & 0.77 & 3.10 & 0.90 \\
Station 5 & 0.31 & 0.33 & 2.95 & 0.95 & 3.30 & 0.97 \\
Station 6 & 0.36 & 0.27 & 2.27 & 0.83 & 2.80 & 0.87 \\
\hline
\end{tabular}

\section{Reference}

[1] M.N. Tijani, S. Onodera and M. A. Adeleye, "Environmental implications of adsorbed and total trace metals concentrations in bottom-sediments of an urban drainage network in a developing country", Materials and Geoenvironment, Vol. 52, No. 1, 2005, pp. 127-130.

[2] S. B. Saha, S.B Abhijit and A. Choudhury, "Status of sediment with special reference to heavy metal pollution of a brackish water tidal ecosystem in northern Sundarbans of West Bengal", Tropical Ecol., Vol. 42, No. 1, 2001, pp. 127-132.

[3] G.E. Batley, "Trace Metal Speciation: Analytical Methods and Problems", CRC Press, Boca Raton, Florida. 1989.

[4] A. Goorzadi, G. Vahabzadeh and A. R. Carbassi, "Assessment of heavy metals pollution in Tilehbon River sediments", Iran Journal of Applied Science, Vol. 9, No. 6, 2009, pp.1190-1193.

[5] G.T. Ankley, K. Lodge, D.J. Call, M.D. Balcer, and B. J. Smith,"Heavy metal concentrations in surface sediments in a near shore environment, Jurujuba Sound, Southeast Brazil", Environmental Pollution, Vol. 109, 1992.

[6] F. T. D. Wakida, E. J. Lara-Ruiz and P. Temores, "Heavy metals in sediments of the Tecate River, Mexico", Environmental Geology, Vol. 54, 2008, pp. 637-642.

[7] M. Singh, A.A. Ansari, G. Muller, and I.B. Singh,"Heavy metals in freshly deposited sediments of the Gomati river a tributary of the Ganga River: Effects of human activities", Environmental Geology, Vol. 29, 1997, pp. 246-252. 
[8] C.P. Priju, and A.C. Narayana, "Spatial and Temporal Variability of Trace Element Concentrations in a Tropical Lagoon, Southwest Coast of India: Environmental Implications", Journal of Coastal Research, Vol.39, 2006, pp.1053 - 1057.

[9] A.W.Sabri, K.A. Rasheed and T.I. Kassim "Heavy metals in the water, suspended solids and sediment of the river Tigris impoundment at Samarra", Water Research, Vol. 27, No. 6, 1993, pp. 1099-1103.

[10] T.I.Kassim, H.A. Al-Saadi, A.A. Al-Lami, and H.H. Al-Jaberi, "Heavy metals in water, suspended particles, sediments and aquatic plants of the upper region of Euphrates river, Iraq", Journal Environmental science Health ,Vol. 32, No. 9 \& 10 , 1997, pp.2497-2506.

[11] A.A. Al-Lami, and H.H. Al-Jaberi, "Heavy metals in water, suspended particles and sediment of the upper-mid region of Tigris River, Iraq", Proceeding of international Symposium on Environmental Pollution Control and Waste management, 7-10 January, 2002, Tunis.

[12] K.A. Rasheed, A.W. Sabri, A. A. AlLami, T. I. Kassim, and S. F. Shawkat, "Distribution of some heavy metals in water, suspended solids, sediments, fish and aquatic plants of the river Tigris, Iraq", Science Journal of Iraqi Atomic Energy Commission, Vol. 3, No. 1, 2001, pp. 198208.

[13] A. I. Al-Juboury, "Natural Pollution By Some Heavy Metals in the Tigris River, Northern Iraq", International Journal. Environmental Research,Vol. 3,No.2, 2009, pp.189-198.

[14] J. Rzoska, "Euphrates and Tigris, Mesopotamia ecology and destiny" W. Junk bv. Pub, The Hague, Boston, London,1980, pp.122.

[15] J.D. Smith, E.C. Bulter and N. Millis, "Distribution and significance of copper lead and cadmium in the Corio Bay ecosystem", Australian Journal Marsh and Fresh water Research, Vol. 32, 1981, pp. 151-164.

[16] J.K. Abaychi, and A. Z. Douabul, "Trace metal in Shatt al-Arab river, Iraq", Water Research, Vol.19, 1985, pp.457-462.
[17] G. Muller, "Index of geoaccumulation in sediments of the Rhine River", Geology Journal, Vol.2, 1969, pp. 109-118.

[18] L. Boszke, T. Sobczynski, and A. Kowalski, "Distribution of Mercury and Other Heavy Metals in Bottom Sediments of the Middle Odra river (Germany/Poland)", Polish Journal of Environmental Studies, Vol. 13, No.5, 2004, pp.495-502.

[19] K.K. Turekian, and K. H. Wedepohl, "Distribution of the elements in some major units of the earth's crust", American Geology Soc. Bulletin, Vol. 72, 1961, pp. $175-182$.

[20] H. M. Soares, R. A. R. Boaventura. and J. Esteves da Silva, "Sediments as Monitors of Heavy Metal Contamination in the Ave River Basin (Portugal): Multivariate Analysis of Data", Environmental Pollution, Vol. 105, 1999, pp.311-323.

[21] D.L. Tomlinson, J.G. Wilson, C.R. Harris, and D.W. Jeffney, "Problems in the assessment of heavy metal levels in estuaries and the formation of a pollution index", Helgol. Wiss. Meeresunters, Vol.33, 1980, pp. 566-572.

[22] P. S. Harikumar, U. P Nasir and M. P. Mujeebu Rahma, "Distribution of heavy metals in the core sediments of a tropical wetland system, "International Journal. Environmental Science Technology, Vol. 6, No. 2, 2009, pp.225-232.

[23] W. N. Saloman, H. Rooij, and J. Bril, "Sediments as a source for contaminants", Hydrobiologia, Vol. 149, 1987, pp.13-30.

[24] G.G. Gessey, L. Borstad and P. M. Chapman, "Influence of flow related events concentrations and phase distribution of metals in the lower Fraser river and a small tributary stream in British Columbia", Canada Water Research, Vol. 18, 1984, pp. 233-238.

[25] V.K. Singh, K.P. Singh and D. Mohan, "Status of heavy metals in water and bed sediments of river Gomti - A tributary of the Ganga river, India", Environmental Monitoring and Assessment, Vol. 105, 2005, pp. 43-67.

[26] J. Mwamburi, "Variations in trace elements in bottom sediments of major rivers in Lake Victoria's basin, Kenya", 
Lakes \& Reservoirs: Research and Management, Vol. 8, 2003, pp. 5-13.

[27] K.O Adebowale, F.O. Agunbide, and B. Olu-Owolabi, "Trace metal concentration, site variations and partitioning pattern in water and bottom sediments from coastal area : A case study of Ondo Coast, Nigeria", Environmental Research Journal, Vol.3, No.2, 2009, pp. 46-59.

[28] M. S. Praveena, M. Radojevic and M. H. Abdullah, "The Assessment of Mangrove Sediment Quality in Mengkabong Lagoon: An Index Analysis Approach”, International Journal of Environmental \& Science Education, Vol. 2, No. 3, 2007, pp. $60-68$.

الخلاصة

نم انتخاب ست محطات على طول نهر دجلة في منطقة

بغداد لغرض جمع وتقييم تلوث الرواسب بمعادن المنغنيز،

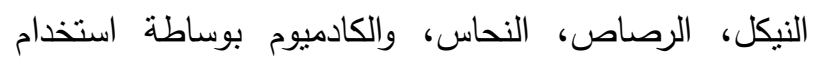
مؤشر حمل التلوث (PLI) ومؤشر التراكم الارضي لترهي (I-geo). اشارت النتائج الى تسجيل عنصر الكادميوم اقل التراكيز مقارنة بالعناصر الاخرى المدروسة، حيث نراوحت قيمه ما بين 0.3 الى 1.3 مايكروغرام لكل غرام من الوزن الجاف للرواسب، بينما سجل المنغنيز اعلى التراكيز ( - 426

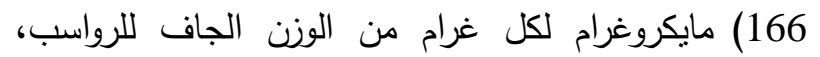
وانشار مؤشر التراكم الارضي الى ان الرواسب في اغلب محطات الدراسة تعد ذات نلوث خفيف بعنصري الرصاص

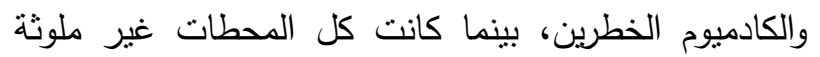
بعناصر المنغنيز والنحاس والنيكل. وجدت قيم قليلة لمؤشر حمل التلوث وتراوحت ما بين 0.301 - 0.970 مما بشير وبشكل عام الى ان محطات الدراسة تعد غير ملوثة بمجموع لمان

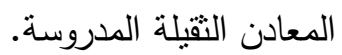

